\title{
Eicosanoid turnover in GtoPdb v.2021.3
}

\author{
Angelo A. Izzo ${ }^{1}$ and Jane A. Mitchell ${ }^{2}$
}

1. University of Naples Federico II, Italy

2. Imperial College London, UK

\begin{abstract}
Eicosanoids are 20-carbon fatty acids, where the usual focus is the polyunsaturated analogue arachidonic acid and its metabolites. Arachidonic acid is thought primarily to derive from phospholipase A2 action on membrane phosphatidylcholine, and may be re-cycled to form phospholipid through conjugation with coenzyme A and subsequently glycerol derivatives. Oxidative metabolism of arachidonic acid is conducted through three major enzymatic routes: cyclooxygenases; lipoxygenases and cytochrome P450-like epoxygenases, particularly CYP2J2. Isoprostanes are structural analogues of the prostanoids (hence the nomenclature D-, E-, F-isoprostanes and isothromboxanes), which are produced in the presence of elevated free radicals in a non-enzymatic manner, leading to suggestions for their use as biomarkers of oxidative stress. Molecular targets for their action have yet to be defined.
\end{abstract}

\section{Contents}

This is a citation summary for Eicosanoid turnover in the Guide to Pharmacology database (GtoPdb). It exists purely as an adjunct to the database to facilitate the recognition of citations to and from the database by citation analyzers. Readers will almost certainly want to visit the relevant sections of the database which are given here under database links.

GtoPdb is an expert-driven guide to pharmacological targets and the substances that act on them. GtoPdb is a reference work which is most usefully represented as an on-line database. As in any publication this work should be appropriately cited, and the papers it cites should also be recognized. This document provides a citation for the relevant parts of the database, and also provides a reference list for the research cited by those parts. For further details see [16].

Please note that the database version for the citations given in GtoPdb are to the most recent preceding version in which the family or its subfamilies and targets were substantially changed. The links below are to the current version. If you need to consult the cited version, rather than the most recent version, please contact the GtoPdb curators.

\section{Database links}

Eicosanoid turnover

https://www.guidetopharmacology.org/GRAC/FamilyDisplayForward?familyId=243

Cyclooxygenase

https://www.guidetopharmacology.org/GRAC/FamilyDisplayForward?familyId=269

Enzymes

COX-1

https://www.guidetopharmacology.org/GRAC/ObjectDisplayForward?objectId=1375 COX-2

https://www.guidetopharmacology.org/GRAC/ObjectDisplayForward?objectId=1376

Prostaglandin synthases

https://www.guidetopharmacology.org/GRAC/FamilyDisplayForward?familyId=270

Enzymes

Thromboxane-A synthase(CYP5A1)

https://www.guidetopharmacology.org/GRAC/ObjectDisplayForward?objectId=1353

Prostacyclin synthase(CYP8A1)

https://www.guidetopharmacology.org/GRAC/ObjectDisplayForward?objectId=1356 
mPGES1

https://www.guidetopharmacology.org/GRAC/ObjectDisplayForward?objectId=1377 mPGES2

https://www.guidetopharmacology.org/GRAC/ObjectDisplayForward?objectId=1378 cPGES

https://www.guidetopharmacology.org/GRAC/ObjectDisplayForward?objectId=1379 L-PGDS

https://www.guidetopharmacology.org/GRAC/ObjectDisplayForward?objectId=1380 H-PGDS

https://www.guidetopharmacology.org/GRAC/ObjectDisplayForward?objectId=1381 AKR1C3

https://www.guidetopharmacology.org/GRAC/ObjectDisplayForward?objectId=1382 CBR1

https://www.guidetopharmacology.org/GRAC/ObjectDisplayForward?objectId=1383 HPGD

https://www.guidetopharmacology.org/GRAC/ObjectDisplayForward?objectId=1384 Lipoxygenases

https://www.guidetopharmacology.org/GRAC/FamilyDisplayForward?familyId=271

Enzymes

5-LOX

https://www.guidetopharmacology.org/GRAC/ObjectDisplayForward?objectId=1385 12R-LOX

https://www.guidetopharmacology.org/GRAC/ObjectDisplayForward?objectId=1386 12S-LOX

https://www.guidetopharmacology.org/GRAC/ObjectDisplayForward?objectId=1387 15-LOX-1

https://www.guidetopharmacology.org/GRAC/ObjectDisplayForward?objectId=1388 15-LOX-2

https://www.guidetopharmacology.org/GRAC/ObjectDisplayForward?objectId=1389 E-LOX

https://www.guidetopharmacology.org/GRAC/ObjectDisplayForward?objectId=1390

Leukotriene and lipoxin metabolism

https://www.guidetopharmacology.org/GRAC/FamilyDisplayForward?familyId=272

Enzymes

Leukotriene C4 synthase

https://www.guidetopharmacology.org/GRAC/ObjectDisplayForward?objectId=1391 $\gamma$-Glutamyltransferase

https://www.guidetopharmacology.org/GRAC/ObjectDisplayForward?objectId=1392 Dipeptidase 1

https://www.guidetopharmacology.org/GRAC/ObjectDisplayForward?objectId=1393 Dipeptidase 2

https://www.guidetopharmacology.org/GRAC/ObjectDisplayForward?objectId=1394 Leukotriene $\mathrm{A}_{4}$ hydrolase

https://www.guidetopharmacology.org/GRAC/ObjectDisplayForward?objectId=1395

\section{References}

1. Abdelgawad MA, Labib MB, Ali WAM, Kamel G, Azouz AA and El-Nahass ES. (2018) Design, synthesis, analgesic, anti-inflammatory activity of novel pyrazolones possessing aminosulfonyl pharmacophore as inhibitors of COX-2/5-LOX enzymes: Histopathological and docking studies. Bioorg Chem 78: 103-114 [PMID:29550530]

2. Adams JL, Smothers J, Srinivasan R and Hoos A. (2015) Big opportunities for small molecules in immuno-oncology. Nat Rev Drug Discov 14: 603-22 [PMID:26228631]

3. Allen L, Meck R and Yunis A. (1980) The inhibition of gamma-glutamyl transpeptidase from human pancreatic carcinoma cells by (alpha S,5S)-alpha-amino-3-chloro-4,5-dihydro-5isoxazoleacetic acid (AT-125; NSC-163501). Res Commun Chem Pathol Pharmacol 27: 175-82 [PMID:6102405]

4. Aritake K, Kado Y, Inoue T, Miyano M and Urade Y. (2006) Structural and functional characterization of HQL-79, an orally selective inhibitor of human hematopoietic prostaglandin D synthase. J Biol Chem 281: 15277-86 [PMID:16547010]

5. Auerbach SS and DrugMatrix ${ }^{\circledR}$ and ToxFX ${ }^{\circledR}$ Coordinator National Toxicology Program.. National Toxicology Program: Dept of Health and Human Services.

6. Bayly CI, Black WC, Léger S, Ouimet N, Ouellet M and Percival MD. (1999) Structure-based design of COX-2 selectivity into flurbiprofen. Bioorg Med Chem Lett 9: 307-12 [PMID:10091674]

7. Beswick P, Bingham S, Bountra C, Brown T, Browning K, Campbell I, Chessell I, Clayton N, Collins S and Corfield J et al.. (2004) Identification of 2,3-diaryl-pyrazolo[1,5-b]pyridazines as 
potent and selective cyclooxygenase-2 inhibitors. Bioorg Med Chem Lett 14: 5445-8 [PMID:15454242]

8. Bhagwat SS, Gude C, Boswell C, Contardo N, Cohen DS, Dotson R, Mathis J, Lee W, Furness P and Zoganas H. (1992) Thromboxane receptor antagonism combined with thromboxane synthase inhibition. 4. 8-[[(4-Chlorophenyl)sulfonyl]amino]-4-(3-(3-pyridinyl) propyl)octanoic acid and analogs. J Med Chem 35: 4373-83 [PMID:1447738]

9. Bigby TD. (2000) The leukotriene C(4) synthase gene and asthma. Am J Respir Cell Mol Biol 23: 273-6 [PMID:10970815]

10. Bigby TD, Hodulik CR, Arden KC and Fu L. (1996) Molecular cloning of the human leukotriene C4 synthase gene and assignment to chromosome 5q35. Mol Med 2: 637-46 [PMID:8898379]

11. Black WC, Brideau C, Chan CC, Charleson S, Cromlish W, Gordon R, Grimm EL, Hughes G, Leger S and Li CS et al.. (2003) 3,4-Diaryl-5-hydroxyfuranones: highly selective inhibitors of cyclooxygenase-2 with aqueous solubility. Bioorg Med Chem Lett 13: 1195-8 [PMID:12643942]

12. Blobaum AL and Marnett LJ. (2007) Molecular determinants for the selective inhibition of cyclooxygenase-2 by lumiracoxib. J Biol Chem 282: 16379-90 [PMID:17434872]

13. Blobaum AL and Marnett LJ. (2007) Structural and functional basis of cyclooxygenase inhibition. J Med Chem 50: 1425-41 [PMID:17341061]

14. Bollbuck B, Merkert C, Miltz W and Roehn T. (2015) Heteroaryl butanoic acid derivatives as lta4h inhibitors Patent number: WO2015092740A1.

15. Bonnard E, Poras H, Nadal X, Maldonado R, Fournié-Zaluski MC and Roques BP. (2015) Longlasting oral analgesic effects of N-protected aminophosphinic dual ENKephalinase inhibitors (DENKIs) in peripherally controlled pain. Pharmacol Res Perspect 3: e00116 [PMID:25692029]

16. Buneman P, Christie G, Davies JA, Dimitrellou R, Harding SD, Pawson AJ, Sharman JL and Wu Y. (2020) Why data citation isn't working, and what to do about it Database 2020 [PMID:32367113]

17. Bézière N, Goossens L, Pommery J, Vezin H, Touati N, Hénichart JP and Pommery N. (2008) New NSAIDs-NO hybrid molecules with antiproliferative properties on human prostatic cancer cell lines. Bioorg Med Chem Lett 18: 4655-7 [PMID:18667313]

18. Carter GW, Young PR, Albert DH, Bouska J, Dyer R, Bell RL, Summers JB and Brooks DW. (1991) 5-lipoxygenase inhibitory activity of zileuton. J Pharmacol Exp Ther 256: 929-37 [PMID:1848634]

19. Chaaban I, Rizk OH, Ibrahim TM, Henen SS, El-Khawass EM, Bayad AE, El-Ashmawy IM and Nematalla HA. (2018) Synthesis, anti-inflammatory screening, molecular docking, and COX1,2/-5-LOX inhibition profile of some novel quinoline derivatives. Bioorg Chem 78: 220-235 [PMID:29602046]

20. Chadli A, Bouhouche I, Sullivan W, Stensgard B, McMahon N, Catelli MG and Toft DO. (2000) Dimerization and N-terminal domain proximity underlie the function of the molecular chaperone heat shock protein 90. Proc Natl Acad Sci USA 97: 12524-9 [PMID:11050175]

21. Chen X, Wang S, Wu N and Yang CS. (2004) Leukotriene A4 hydrolase as a target for cancer prevention and therapy. Curr Cancer Drug Targets 4: 267-83 [PMID:15134534]

22. Cho H, Ueda M, Tamaoka M, Hamaguchi M, Aisaka K, Kiso Y, Inoue T, Ogino R, Tatsuoka T and Ishihara T et al.. (1991) Novel caffeic acid derivatives: extremely potent inhibitors of 12lipoxygenase. J Med Chem 34: 1503-5 [PMID:2016727]

23. Chowdhury MA, Abdellatif KR, Dong Y, Das D, Yu G, Velázquez CA, Suresh MR and Knaus EE. (2009) Synthesis and biological evaluation of salicylic acid and N-acetyl-2-

carboxybenzenesulfonamide regioisomers possessing a N-difluoromethyl-1,2-dihydropyrid-2-one pharmacophore: dual inhibitors of cyclooxygenases and 5-lipoxygenase with anti-inflammatory activity. Bioorg Med Chem Lett 19: 6855-61 [PMID:19884005]

24. Dixon RA, Diehl RE, Opas E, Rands E, Vickers PJ, Evans JF, Gillard JW and Miller DK. (1990) Requirement of a 5-lipoxygenase-activating protein for leukotriene synthesis. Nature 343: 282-4 [PMID:2300173]

25. El-Nagar MKS, Abdu-Allah HHM, Salem OIA, Kafafy AN and Farghaly HSM. (2018) Novel Nsubstituted 5-aminosalicylamides as dual inhibitors of cyclooxygenase and 5-lipoxygenase enzymes: Synthesis, biological evaluation and docking study. Bioorg Chem 78: 80-93 [PMID:29550533]

26. Faull AW, Brewster AG, Brown GR, Smithers MJ and Jackson R. (1995) Dual-acting thromboxane receptor antagonist/synthase inhibitors: synthesis and biological properties of [2-substituted-4(3-pyridyl)-1,3-dioxan-5-yl] alkenoic acids. J Med Chem 38: 686-94 [PMID:7861416]

27. Fischer L, Steinhilber D and Werz O. (2004) Molecular pharmacological profile of the nonredoxtype 5-lipoxygenase inhibitor CJ-13,610. Br J Pharmacol 142: 861-8 [PMID:15197110]

28. Fürstenberger G, Marks F and Krieg P. (2002) Arachidonate 8(S)-lipoxygenase. Prostaglandins Other Lipid Mediat 68-69: 235-43 [PMID:12432921]

29. Garscha U, Romp E, Pace S, Rossi A, Temml V, Schuster D, König S, Gerstmeier J, Liening S and Werner M et al.. (2017) Pharmacological profile and efficiency in vivo of diflapolin, the first dual inhibitor of 5-lipoxygenase-activating protein and soluble epoxide hydrolase. Sci Rep 7: 9398 
[PMID:28839250]

30. Geisslinger G and Schaible HG. (1996) New insights into the site and mode of antinociceptive action of flurbiprofen enantiomers. J Clin Pharmacol 36: 513-20 [PMID:8809636]

31. Geusens P. (2009) Naproxcinod, a new cyclooxygenase-inhibiting nitric oxide donator (CINOD). Expert Opin Biol Ther 9: 649-57 [PMID:19392579]

32. Gierse JK, McDonald JJ, Hauser SD, Rangwala SH, Koboldt CM and Seibert K. (1996) A single amino acid difference between cyclooxygenase-1 (COX-1) and -2 (COX-2) reverses the selectivity of COX-2 specific inhibitors. J Biol Chem 271: 15810-4 [PMID:8663121]

33. Giroux A, Boulet L, Brideau C, Chau A, Claveau D, Côté B, Ethier D, Frenette R, Gagnon M and Guay J et al.. (2009) Discovery of disubstituted phenanthrene imidazoles as potent, selective and orally active mPGES-1 inhibitors. Bioorg Med Chem Lett 19: 5837-41 [PMID:19748780]

34. Gorman RR, Johnson RA, Spilman CH and Aiken JW. (1983) Inhibition of platelet thromboxane A2 synthase activity by sodium 5-(3'-pyridinylmethyl)benzofuran-2-carboxylate. Prostaglandins 26: 325-42 [PMID:6316421]

35. Graham DW, Ashton WT, Barash L, Brown JE, Brown RD, Canning LF, Chen A, Springer JP and Rogers EF. (1987) Inhibition of the mammalian beta-lactamase renal dipeptidase (dehydropeptidase-I) by (Z)-2-(acylamino)-3-substituted-propenoic acids. J Med Chem 30: 107490 [PMID:3495664]

36. Gresele P, Deckmyn H, Arnout J, Nenci GG and Vermylen J. (1989) Characterization of N,N'bis(3-picolyl)-4-methoxy-isophtalamide (picotamide) as a dual thromboxane synthase inhibitor/thromboxane A2 receptor antagonist in human platelets. Thromb Haemost 61: 479-84 [PMID:2552606]

37. Gryglewski RJ, Bunting S, Moncada S, Flower RJ and Vane JR. (1976) Arterial walls are protected against deposition of platelet thrombi by a substance (prostaglandin X) which they make from prostaglandin endoperoxides. Prostaglandins 12: 685-713 [PMID:824685]

38. Gryglewski RJ, Szczeklik A, Korbut R, Swies J, Musiał J, Krzanowski M and Maga P. (1995) The mechanism of anti-thrombotic, thrombolytic and fibrinolytic actions of camonagrel--a new thromboxane synthase inhibitor. Wien Klin Wochenschr 107: 283-9 [PMID:7778318]

39. Han L, Hiratake J, Kamiyama A and Sakata K. (2007) Design, synthesis, and evaluation of gamma-phosphono diester analogues of glutamate as highly potent inhibitors and active site probes of gamma-glutamyl transpeptidase. Biochemistry 46: 1432-47 [PMID:17260973]

40. Hatae T, Hara S, Yokoyama C, Yabuki T, Inoue H, Ullrich V and Tanabe T. (1996) Site-directed mutagenesis of human prostacyclin synthase: Alteration of Cys441 of the Cys-pocket, and Glu347 and Arg350 of the EXXR motif. FEBS Lett 389: 268-72 [PMID:8766713]

41. Hatzelmann A, Fruchtmann R, Mohrs KH, Raddatz S and Müller-Peddinghaus R. (1993) Mode of action of the new selective leukotriene synthesis inhibitor BAY X 1005 ((R)-2-[4-(quinolin-2-y]methoxy)phenyl]-2-cyclopentyl acetic acid) and structurally related compounds. Biochem Pharmacol 45: 101-11 [PMID:8381000]

42. Heinrich DM, Flanagan JU, Jamieson SM, Silva S, Rigoreau LJ, Trivier E, Raynham T, Turnbull AP and Denny WA. (2013) Synthesis and structure-activity relationships for 1-(4-(piperidin-1ylsulfonyl)phenyl)pyrrolidin-2-ones as novel non-carboxylate inhibitors of the aldo-keto reductase enzyme AKR1C3. Eur J Med Chem 62: 738-44 [PMID:23454516]

43. Hibi S, Okamoto Y, Tagami K, Numata H, Kobayashi N, Shinoda M, Kawahara T, Harada K, Miyamoto K and Yamatsu I. (1996) Structure-activity relationships of (E)-3-(1,4benzoquinonyl)-2-[(3-pyridyl)-alkyl]-2-propenoic acid derivatives that inhibit both 5-lipoxygenase and thromboxane A2 synthetase. J Med Chem 39: 3148-57 [PMID:8759636]

44. Hieke M, Ness J, Steri R, Dittrich M, Greiner C, Werz O, Baumann K, Schubert-Zsilavecz M, Weggen S and Zettl H. (2010) Design, synthesis, and biological evaluation of a novel class of gamma-secretase modulators with PPARgamma activity. J Med Chem 53: 4691-700 [PMID:20503989]

45. Hieke M, Ness J, Steri R, Greiner C, Werz O, Schubert-Zsilavecz M, Weggen S and Zettl H. (2011) SAR studies of acidic dual $\gamma$-secretase/PPAR $\gamma$ modulators. Bioorg Med Chem 19: $5372-82$ [PMID:21873070]

46. Hinz B, Cheremina O and Brune K. (2008) Acetaminophen (paracetamol) is a selective cyclooxygenase-2 inhibitor in man. FASEB J 22: 383-90 [PMID:17884974]

47. Hiraku S, Taniguchi K, Wakitani K, Omawari N, Kira H, Miyamoto T, Okegawa T, Kawasaki A and Ujiie A. (1986) Pharmacological studies on the TXA2 synthetase inhibitor (E)-3-[p-(1Himidazol-1-ylmethyl)phenyl]-2-propenoic acid (OKY-046). Jpn J Pharmacol 41: 393-401 [PMID:3093741]

48. Hoshino J, Park EJ, Kondratyuk TP, Marler L, Pezzuto JM, van Breemen RB, Mo S, Li Y and Cushman M. (2010) Selective synthesis and biological evaluation of sulfate-conjugated resveratrol metabolites. J Med Chem 53: 5033-43 [PMID:20527891]

49. Imanishi J, Morita Y, Yoshimi E, Kuroda K, Masunaga T, Yamagami K, Kuno M, Hamachi E, Aoki S and Takahashi F et al.. (2011) Pharmacological profile of FK881(ASP6537), a novel potent and selective cyclooxygenase-1 inhibitor. Biochem Pharmacol 82: 746-54 [PMID:21745460] 
50. Inagaki M, Tsuri T, Jyoyama H, Ono T, Yamada K, Kobayashi M, Hori Y, Arimura A, Yasui K and Ohno K et al.. (2000) Novel antiarthritic agents with 1,2-isothiazolidine-1,1-dioxide (gammasultam) skeleton: cytokine suppressive dual inhibitors of cyclooxygenase-2 and 5-lipoxygenase. $J$ Med Chem 43: 2040-8 [PMID:10821716]

51. Irikura D, Aritake K, Nagata N, Maruyama T, Shimamoto S and Urade Y. (2009) Biochemical, functional, and pharmacological characterization of AT-56, an orally active and selective inhibitor of lipocalin-type prostaglandin D synthase. J Biol Chem 284: 7623-30 [PMID:19131342]

52. Jameson 2nd JB, Kantz A, Schultz L, Kalyanaraman C, Jacobson MP, Maloney DJ, Jadhav A, Simeonov A and Holman TR. (2014) A high throughput screen identifies potent and selective inhibitors to human epithelial 15-lipoxygenase-2. PLoS ONE 9: e104094 [PMID:25111178]

53. Janusz JM, Young PA, Scherz MW, Enzweiler K, Wu LI, Gan L, Pikul S, McDow-Dunham KL, Johnson CR and Senanayake CB et al.. (1998) New cyclooxygenase-2/5-lipoxygenase inhibitors. 2. 7-tert-butyl-2,3-dihydro-3,3-dimethylbenzofuran derivatives as gastrointestinal safe antiinflammatory and analgesic agents: variations of the dihydrobenzofuran ring. J Med Chem 41: 1124-37 [PMID:9544212]

54. Jegerschöld C, Pawelzik SC, Purhonen P, Bhakat P, Gheorghe KR, Gyobu N, Mitsuoka K, Morgenstern R, Jakobsson PJ and Hebert H. (2008) Structural basis for induced formation of the inflammatory mediator prostaglandin E2. Proc Natl Acad Sci USA 105: 11110-5 [PMID:18682561]

55. Johnson J, Corbisier R, Stensgard B and Toft D. (1996) The involvement of p23, hsp90, and immunophilins in the assembly of progesterone receptor complexes. J Steroid Biochem $\mathrm{Mol}$ Biol 56: 31-7 [PMID:8603045]

56. Kalgutkar AS, Rowlinson SW, Crews BC and Marnett LJ. (2002) Amide derivatives of meclofenamic acid as selective cyclooxygenase-2 inhibitors. Bioorg Med Chem Lett 12: 521-4 [PMID:11844663]

57. Kassab SE, Khedr MA, Ali HI and Abdalla MM. (2017) Discovery of new indomethacin-based analogs with potentially selective cyclooxygenase-2 inhibition and observed diminishing to PGE2 activities. Eur J Med Chem 141: 306-321 [PMID:29031075]

58. Kato M, Nishida S, Kitasato H, Sakata N and Kawai S. (2001) Cyclooxygenase-1 and cyclooxygenase-2 selectivity of non-steroidal anti-inflammatory drugs: investigation using human peripheral monocytes. J Pharm Pharmacol 53: 1679-85 [PMID:11804398]

59. Kawai S, Nishida S, Kato M, Furumaya Y, Okamoto R, Koshino T and Mizushima Y. (1998) Comparison of cyclooxygenase-1 and -2 inhibitory activities of various nonsteroidal antiinflammatory drugs using human platelets and synovial cells. Eur J Pharmacol 347: 87-94 [PMID:9650852]

60. Khanapure SP, Garvey DS, Janero DR and Letts LG. (2007) Eicosanoids in inflammation: biosynthesis, pharmacology, and therapeutic frontiers. Curr Top Med Chem 7: 311-40 [PMID:17305573]

61. Kiefer JR, Pawlitz JL, Moreland KT, Stegeman RA, Hood WF, Gierse JK, Stevens AM, Goodwin DC, Rowlinson SW and Marnett LJ et al.. (2000) Structural insights into the stereochemistry of the cyclooxygenase reaction. Nature 405: 97-101 [PMID:10811226]

62. Kleinschmidt TK, Haraldsson M, Basavarajappa D, Lundeberg E, Thulasingam M, Ekoff M, Fauland A, Lehmann C, Kahnt AS and Lindbom L et al.. (2015) Tandem Benzophenone Amino Pyridines, Potent and Selective Inhibitors of Human Leukotriene C4 Synthase.J Pharmacol Exp Ther 355: 108-16 [PMID:26283693]

63. Kobayashi T, Nakatani Y, Tanioka T, Tsujimoto M, Nakajo S, Nakaya K, Murakami M and Kudo I. (2004) Regulation of cytosolic prostaglandin E synthase by phosphorylation. Biochem J 381: 5969 [PMID:15040786]

64. Koeberle A, Zettl H, Greiner C, Wurglics M, Schubert-Zsilavecz M and Werz O. (2008) Pirinixic acid derivatives as novel dual inhibitors of microsomal prostaglandin E2 synthase-1 and 5lipoxygenase. J Med Chem 51: 8068-76 [PMID:19053751]

65. Kolasa T, Brooks CD, Rodriques KE, Summers JB, Dellaria JF, Hulkower KI, Bouska J, Bell RL and Carter GW. (1997) Nonsteroidal anti-inflammatory drugs as scaffolds for the design of 5lipoxygenase inhibitors. J Med Chem 40: 819-24 [PMID:9057869]

66. Kramer JS, Woltersdorf S, Duflot T, Hiesinger K, Lillich FF, Knöll F, Wittmann SK, Klingler FM, Brunst S and Chaikuad A et al.. (2019) Discovery of the First in Vivo Active Inhibitors of the Soluble Epoxide Hydrolase Phosphatase Domain. J Med Chem 62: 8443-8460 [PMID:31436984]

67. Kumar R, Saha N, Purohit P, Garg SK, Seth K, Meena VS, Dubey S, Dave K, Goyal R and Sharma SS et al.. (2019) Cyclic enaminone as new chemotype for selective cyclooxygenase-2 inhibitory, anti-inflammatory, and analgesic activities. Eur J Med Chem 182: 111601 [PMID:31445233]

68. Lazer ES, Miao CK, Cywin CL, Sorcek R, Wong HC, Meng Z, Potocki I, Hoermann M, Snow RJ and Tschantz MA et al.. (1997) Effect of structural modification of enol-carboxamide-type nonsteroidal antiinflammatory drugs on COX-2/COX-1 selectivity. J Med Chem 40: 980-9 [PMID:9083488]

69. Leclerc P, Idborg H, Spahiu L, Larsson C, Nekhotiaeva N, Wannberg J, Stenberg P, Korotkova M and Jakobsson PJ. (2013) Characterization of a human and murine mPGES-1 inhibitor and 
comparison to mPGES-1 genetic deletion in mouse models of inflammation. Prostaglandins Other Lipid Mediat 107: 26-34 [PMID:24045148]

70. Lee KH, Petruncio G, Shim A, Burdick M, Zhang Z, Shim YM, Noble SM and Paige M. (2019) Effect of Modifier Structure on the Activation of Leukotriene $\mathrm{A}_{4}$ Hydrolase Aminopeptidase Activity. J Med Chem 62: 10605-10616 [PMID:31751136]

71. Liu Y, Duan C, Chen H, Wang C, Liu X, Qiu M, Tang H, Zhang F, Zhou X and Yang J. (2018) Inhibition of COX-2/mPGES-1 and 5-LOX in macrophages by leonurine ameliorates monosodium urate crystal-induced inflammation. Toxicol Appl Pharmacol 351: 1-11 [PMID:29763636]

72. Lolli ML, Carnovale IM, Pippione AC, Wahlgren WY, Bonanni D, Marini E, Zonari D, Gallicchio M, Boscaro V and Goyal P et al.. (2019) Bioisosteres of Indomethacin as Inhibitors of Aldo-Keto Reductase 1C3. ACS Med Chem Lett 10: 437-443 [PMID:30996776]

73. Look GC, Schullek JR, Holmes CP, Chinn JP, Gordon EM and Gallop MA. (1996) The identification of cyclooxygenase-1 inhibitors from 4-thiazolidinone combinatorial libraries. Bioorg Med Chem Lett 6: 707-712

74. Luci DK, Jameson 2nd JB, Yasgar A, Diaz G, Joshi N, Kantz A, Markham K, Perry S, Kuhn N and Yeung J et al.. (2014) Synthesis and structure-activity relationship studies of 4-((2-hydroxy-3methoxybenzyl)amino)benzenesulfonamide derivatives as potent and selective inhibitors of 12lipoxygenase. J Med Chem 57: 495-506 [PMID:24393039]

75. Luo M, Jones SM, Phare SM, Coffey MJ, Peters-Golden M and Brock TG. (2004) Protein kinase A inhibits leukotriene synthesis by phosphorylation of 5-lipoxygenase on serine 523. J Biol Chem 279: 41512-20 [PMID:15280375]

76. Luz JG, Antonysamy S, Kuklish SL, Condon B, Lee MR, Allison D, Yu XP, Chandrasekhar S, Backer R and Zhang A et al.. (2015) Crystal Structures of mPGES-1 Inhibitor Complexes Form a Basis for the Rational Design of Potent Analgesic and Anti-Inflammatory Therapeutics. J Med Chem 58: 4727-37 [PMID:25961169]

77. MacDonald CA, Bushnell EA, Gauld JW and Boyd RJ. (2014) The catalytic formation of leukotriene C4: a critical step in inflammatory processes. Phys Chem Chem Phys 16: 16284-9 [PMID:24974917]

78. Maddox JF and Serhan CN. (1996) Lipoxin A4 and B4 are potent stimuli for human monocyte migration and adhesion: selective inactivation by dehydrogenation and reduction. J Exp Med 183: 137-46 [PMID:8551217]

79. Masferrer JL, Zweifel BS, Hardy M, Anderson GD, Dufield D, Cortes-Burgos L, Pufahl RA and Graneto M. (2010) Pharmacology of PF-4191834, a novel, selective non-redox 5-lipoxygenase inhibitor effective in inflammation and pain. J Pharmacol Exp Ther 334: 294-301 [PMID:20378715]

80. Matsuura K, Shiraishi H, Hara A, Sato K, Deyashiki Y, Ninomiya M and Sakai S. (1998) Identification of a principal mRNA species for human 3alpha-hydroxysteroid dehydrogenase isoform (AKR1C3) that exhibits high prostaglandin D2 11-ketoreductase activity. J Biochem 124: 940-6 [PMID:9792917]

81. Meng H, McClendon CL, Dai Z, Li K, Zhang X, He S, Shang E, Liu Y and Lai L. (2016) Discovery of Novel 15-Lipoxygenase Activators To Shift the Human Arachidonic Acid Metabolic Network toward Inflammation Resolution. J Med Chem 59: 4202-9 [PMID:26290290]

82. Migliore M, Habrant D, Sasso O, Albani C, Bertozzi SM, Armirotti A, Piomelli D and Scarpelli R. (2016) Potent multitarget FAAH-COX inhibitors: Design and structure-activity relationship studies. Eur J Med Chem 109: 216-37 [PMID:26774927]

83. Munck Af Rosenschöld M, Johannesson P, Nikitidis A, Tyrchan C, Chang HF, Rönn R, Chapman D, Ullah V, Nikitidis G and Glader P et al.. (2019) Discovery of the Oral Leukotriene C4 Synthase Inhibitor (1S,2S)-2-(\{5-[(5-Chloro-2,4-difluorophenyl)(2-fluoro-2-methylpropyl)amino]-3methoxypyrazin-2-yl\}carbonyl)cyclopropanecarboxylic Acid (AZD9898) as a New Treatment for Asthma. J Med Chem 62: 7769-7787 [PMID:31415176]

84. Nabe T, Kuriyama Y, Mizutani N, Shibayama S, Hiromoto A, Fujii M, Tanaka K and Kohno S. (2011) Inhibition of hematopoietic prostaglandin D synthase improves allergic nasal blockage in guinea pigs. Prostaglandins Other Lipid Mediat 95: 27-34 [PMID:21601002]

85. Nandha B, Ramareddy SA and Kuntal H. (2018) Synthesis of substituted fluorobenzimidazoles as inhibitors of 5-lipoxygenase and soluble epoxide hydrolase for anti-inflammatory activity. Arch Pharm (Weinheim) 351: e1800030 [PMID:29732612]

86. Ochi T, Motoyama Y and Goto T. (2000) The analgesic effect profile of FR122047, a selective cyclooxygenase-1 inhibitor, in chemical nociceptive models. Eur J Pharmacol 391: 49-54 [PMID:10720634]

87. Oh SF, Pillai PS, Recchiuti A, Yang R and Serhan CN. (2011) Pro-resolving actions and stereoselective biosynthesis of $18 \mathrm{~S}$ E-series resolvins in human leukocytes and murine inflammation. J Clin Invest 121: 569-81 [PMID:21206090]

88. Orning L, Krivi G and Fitzpatrick FA. (1991) Leukotriene A4 hydrolase. Inhibition by bestatin and intrinsic aminopeptidase activity establish its functional resemblance to metallohydrolase enzymes. J Biol Chem 266: 1375-8 [PMID:1846352] 
89. Ottanà R, Carotti S, Maccari R, Landini I, Chiricosta G, Caciagli B, Vigorita MG and Mini E. (2005) In vitro antiproliferative activity against human colon cancer cell lines of representative 4-thiazolidinones. Part I. Bioorg Med Chem Lett 15: 3930-3 [PMID:15993594]

90. Ozen G, Gomez I, Daci A, Deschildre C, Boubaya L, Teskin O, Uydeş-Doğan BS, Jakobsson PJ, Longrois D and Topal G et al.. (2017) Inhibition of microsomal PGE synthase-1 reduces human vascular tone by increasing PGI2 : a safer alternative to COX-2 inhibition. Br J Pharmacol 174: 4087-4098 [PMID:28675448]

91. P JJ, Manju SL, Ethiraj KR and Elias G. (2018) Safer anti-inflammatory therapy through dual COX-2/5-LOX inhibitors: A structure-based approach. Eur J Pharm Sci 121: 356-381 [PMID:29883727]

92. Payne AN, Jackson WP, Salmon JA, Nicholls A, Yeadon M and Garland LG. (1991) Hydroxamic acids and hydroxyureas as novel, selective 5-lipoxygenase inhibitors for possible use in asthma. Agents Actions Suppl 34: 189-99 [PMID:1793063]

93. Penning TD, Askonas LJ, Djuric SW, Haack RA, Yu SS, Michener ML, Krivi GG and Pyla E. (1995) Kelatorphan and related analogs: potent and selective inhibitors of leukotriene A4 hydrolase Bioorganic and Medicinal Chemistry Letters 5: 2517-2522

94. Penning TD, Chandrakumar NS, Chen BB, Chen HY, Desai BN, Djuric SW, Docter SH, Gasiecki AF, Haack RA and Miyashiro JM et al.. (2000) Structure-activity relationship studies on 1-[2-(4Phenylphenoxy)ethyl]pyrrolidine (SC-22716), a potent inhibitor of leukotriene A(4) (LTA(4)) hydrolase. J Med Chem 43: 721-35 [PMID:10691697]

95. Penning TD, Talley JJ, Bertenshaw SR, Carter JS, Collins PW, Docter S, Graneto MJ, Lee LF, Malecha JW and Miyashiro JM et al.. (1997) Synthesis and biological evaluation of the 1,5diarylpyrazole class of cyclooxygenase-2 inhibitors: identification of 4-[5-(4-methylphenyl)-3(trifluoromethyl)-1H-pyrazol-1-yl]benze nesulfonamide (SC-58635, celecoxib). J Med Chem 40: 1347-65 [PMID:9135032]

96. Penrose JF, Spector J, Baldasaro M, Xu K, Boyce J, Arm JP, Austen KF and Lam BK. (1996) Molecular cloning of the gene for human leukotriene C4 synthase. Organization, nucleotide sequence, and chromosomal localization to 5q35. J Biol Chem 271: 11356-61 [PMID:8626689]

97. Prasher P, Pooja and Singh P. (2014) Lead modification: amino acid appended indoles as highly effective 5-LOX inhibitors. Bioorg Med Chem 22: 1642-8 [PMID:24508141]

98. Qiu W, Zhou M, Mazumdar M, Azzi A, Ghanmi D, Luu-The V, Labrie F and Lin SX. (2007) Structure-based inhibitor design for an enzyme that binds different steroids: a potent inhibitor for human type 5 17beta-hydroxysteroid dehydrogenase. J Biol Chem 282: 8368-79 [PMID:17166832]

99. Rai G, Joshi N, Perry S, Yasgar A, Schultz L, Jung JE, Liu Y, Terasaki Y, Diaz G and Kenyon V et al.. (2010) Discovery of ML351, a Potent and Selective Inhibitor of Human 15-Lipoxygenase-1 Probe Reports from the NIH Molecular Libraries Program [PMID:24672829]

100. Rai G, Kenyon V, Jadhav A, Schultz L, Armstrong M, Jameson JB, Hoobler E, Leister W, Simeonov A and Holman TR et al.. (2010) Discovery of potent and selective inhibitors of human reticulocyte 15-lipoxygenase-1. J Med Chem 53: 7392-404 [PMID:20866075]

101. Randall MJ, Parry MJ, Hawkeswood E, Cross PE and Dickinson RP. (1981) UK-37, 248, a novel, selective thromboxane synthetase inhibitor with platelet anti-aggregatory and anti-thrombotic activity. Thromb Res 23: 145-62 [PMID:6795753]

102. Rao NL, Riley JP, Banie H, Xue X, Sun B, Crawford S, Lundeen KA, Yu F, Karlsson L and Fourie AM et al.. (2010) Leukotriene A(4) hydrolase inhibition attenuates allergic airway inflammation and hyperresponsiveness. Am J Respir Crit Care Med 181: 899-907 [PMID:20110560]

103. Riendeau D, Aspiotis R, Ethier D, Gareau Y, Grimm EL, Guay J, Guiral S, Juteau H, Mancini JA and Méthot $\mathrm{N}$ et al.. (2005) Inhibitors of the inducible microsomal prostaglandin E2 synthase (mPGES-1) derived from MK-886. Bioorg Med Chem Lett 15: 3352-5 [PMID:15953724]

104. Riendeau D, Percival MD, Brideau C, Charleson S, Dubé D, Ethier D, Falgueyret JP, Friesen RW, Gordon R and Greig G et al.. (2001) Etoricoxib (MK-0663): preclinical profile and comparison with other agents that selectively inhibit cyclooxygenase-2.J Pharmacol Exp Ther 296: 558-66 [PMID:11160644]

105. Ronn R, Lindh CJ, Ringberg E, Andersson EHB, Nilsson P, Schall WR, Munk af RM, Nikitidis A, Nikitidis G and Johannesson PJ et al.. (2016) Cyclopropane carboxylic acid derivatives and pharmaceutical uses thereof Patent number: WO2016177845.

106. Sadik CD, Sies H and Schewe T. (2003) Inhibition of 15-lipoxygenases by flavonoids: structureactivity relations and mode of action. Biochem Pharmacol 65: 773-81 [PMID:12628491]

107. Sandanayaka V, Mamat B, Mishra RK, Winger J, Krohn M, Zhou LM, Keyvan M, Enache L, Sullins D and Onua E et al.. (2010) Discovery of 4-[(2S)-2-\{[4-(4-

chlorophenoxy)phenoxy]methyl\}-1-pyrrolidinyl]butanoic acid (DG-051) as a novel leukotriene A4 hydrolase inhibitor of leukotriene B4 biosynthesis. J Med Chem 53: 573-85 [PMID:19950900]

108. Schühly W, Hüfner A, Pferschy-Wenzig EM, Prettner E, Adams M, Bodensieck A, Kunert O, Oluwemimo A, Haslinger E and Bauer R. (2009) Design and synthesis of ten biphenyl-neolignan derivatives and their in vitro inhibitory potency against cyclooxygenase-1/2 activity and 5lipoxygenase-mediated LTB4-formation. Bioorg Med Chem 17: 4459-65 [PMID:19481465] 
109. Sendobry SM, Cornicelli JA, Welch K, Bocan T, Tait B, Trivedi BK, Colbry N, Dyer RD, Feinmark SJ and Daugherty A. (1997) Attenuation of diet-induced atherosclerosis in rabbits with a highly selective 15-lipoxygenase inhibitor lacking significant antioxidant properties. BrJ Pharmacol 120: 1199-206 [PMID:9105693]

110. Shiro T, Kakiguchi K, Takahashi H, Nagata H and Tobe M. (2013) 7-Phenyl-imidazoquinolin$4(5 \mathrm{H})$-one derivatives as selective and orally available mPGES-1 inhibitors. Bioorg Med Chem 21: 2868-78 [PMID:23623673]

111. Singh P, Kaur S, Kaur J, Singh G and Bhatti R. (2016) Rational Design of Small Peptides for Optimal Inhibition of Cyclooxygenase-2: Development of a Highly Effective Anti-Inflammatory Agent. J Med Chem 59: 3920-34 [PMID:27019010]

112. Singh P, Prasher P, Dhillon P and Bhatti R. (2015) Indole based peptidomimetics as antiinflammatory and anti-hyperalgesic agents: Dual inhibition of 5-LOX and COX-2 enzymes. Eur J Med Chem 97: 104-23 [PMID:25956953]

113. Sinha S, Doble M and Manju SL. (2018) Design, synthesis and identification of novel substituted 2-amino thiazole analogues as potential anti-inflammatory agents targeting 5-lipoxygenase. Eur J Med Chem 158: 34-50 [PMID:30199704]

114. Skarydová L, Zivná L, Xiong G, Maser E and Wsól V. (2009) AKR1C3 as a potential target for the inhibitory effect of dietary flavonoids. Chem Biol Interact 178: 138-44 [PMID:19007764]

115. Smith CJ, Zhang Y, Koboldt CM, Muhammad J, Zweifel BS, Shaffer A, Talley JJ, Masferrer JL, Seibert K and Isakson PC. (1998) Pharmacological analysis of cyclooxygenase-1 in inflammation. Proc Natl Acad Sci USA 95: 13313-8 [PMID:9789085]

116. Stsiapanava A, Samuelsson B and Haeggström JZ. (2017) Capturing $\mathrm{LTA}_{4}$ hydrolase in action: Insights to the chemistry and dynamics of chemotactic $\mathrm{LTB}_{4}$ synthesis. Proc Natl Acad Sci USA 114: 9689-9694 [PMID:28827365]

117. Takahashi T and Miyazawa M. (2012) N-Caffeoyl serotonin as selective COX-2 inhibitor. Bioorg Med Chem Lett 22: 2494-6 [PMID:22386242]

118. Talley JJ, Brown DL, Carter JS, Graneto MJ, Koboldt CM, Masferrer JL, Perkins WE, Rogers RS, Shaffer AF and Zhang YY et al.. (2000) 4-[5-Methyl-3-phenylisoxazol-4-yl]- benzenesulfonamide, valdecoxib: a potent and selective inhibitor of COX-2. J Med Chem 43: 775-7 [PMID:10715145]

119. Tandon M, Sant S, Khairatkar-Joshi N, Gudi G, Menon VCA and Talluri R. (2019) Mpges-1 inhibitor for the treatment of osteoarthritis pain Patent number: WO2013186692A1.

120. Tholander F, Muroya A, Roques BP, Fournié-Zaluski MC, Thunnissen MM and Haeggström JZ. (2008) Structure-based dissection of the active site chemistry of leukotriene A4 hydrolase: implications for M1 aminopeptidases and inhibitor design. Chem Biol 15: 920-9 [PMID:18804029]

121. Uddin MJ, Xu S, Crews BC, Ghebreselasie K, Banerjee S and Marnett LJ. (2020) Harmaline Analogs as Substrate-Selective Cyclooxygenase-2 Inhibitors ACS Med Chem Lett

122. Verma K, Gupta N, Zang T, Wangtrakluldee P, Srivastava SK, Penning TM and Trippier PC. (2018) AKR1C3 Inhibitor KV-37 Exhibits Antineoplastic Effects and Potentiates Enzalutamide in Combination Therapy in Prostate Adenocarcinoma Cells. Mol Cancer Ther 17: 1833-1845 [PMID:29891491]

123. Viegas A, Manso J, Corvo MC, Marques MM and Cabrita EJ. (2011) Binding of ibuprofen, ketorolac, and diclofenac to COX-1 and COX-2 studied by saturation transfer difference NMR. $J$ Med Chem 54: 8555-62 [PMID:22091869]

124. Wannberg J, Alterman M, Malm J, Stenberg P, Westman J and Wallberg H. (2011) Microsomal prostaglandin e synthase-1 (mpges1) inhibitors Patent number: WO2011023812.

125. Warner TD, Giuliano F, Vojnovic I, Bukasa A, Mitchell JA and Vane JR. (1999) Nonsteroid drug selectivities for cyclo-oxygenase-1 rather than cyclo-oxygenase-2 are associated with human gastrointestinal toxicity: a full in vitro analysis. Proc Natl Acad Sci USA 96: 7563-8 [PMID:10377455]

126. Watanabe K, Ohkubo H, Niwa H, Tanikawa N, Koda N, Ito S and Ohmiya Y. (2003) Essential 110Cys in active site of membrane-associated prostaglandin E synthase-2. Biochem Biophys Res Commun 306: 577-81 [PMID:12804604]

127. Weinstein DS, Liu W, Ngu K, Langevine C, Combs DW, Zhuang S, Chen C, Madsen CS, Harper TW and Robl JA. (2007) Discovery of selective imidazole-based inhibitors of mammalian 15lipoxygenase: highly potent against human enzyme within a cellular environment. Bioorg Med Chem Lett 17: 5115-20 [PMID:17656086]

128. Wilkerson WW, Copeland RA, Covington M and Trzaskos JM. (1995) Antiinflammatory 4,5diarylpyrroles. 2. Activity as a function of cyclooxygenase-2 inhibition. J Med Chem 38: 3895901 [PMID:7562922]

129. Wu Y, Karna S, Choi CH, Tong M, Tai HH, Na DH, Jang CH and Cho H. (2011) Synthesis and biological evaluation of novel thiazolidinedione analogues as 15-hydroxyprostaglandin dehydrogenase inhibitors. J Med Chem 54: 5260-4 [PMID:21650226]

130. Yu Z, Schneider C, Boeglin WE, Marnett LJ and Brash AR. (2003) The lipoxygenase gene ALOXE3 implicated in skin differentiation encodes a hydroperoxide isomerase. Proc Natl Acad 
Sci USA 100: 9162-7 [PMID:12881489]

131. Zhang Z, Ghosh A, Connolly PJ, King P, Wilde T, Wang J, Dong Y, Li X, Liao D and Chen H et al.. (2021) Gut-Restricted Selective Cyclooxygenase-2 (COX-2) Inhibitors for Chemoprevention of Colorectal Cancer. J Med Chem 64: 11570-11596 [PMID:34279934]

132. Zhou H, Liu W, Su Y, Wei Z, Liu J, Kolluri SK, Wu H, Cao Y, Chen J and Wu Y et al.. (2010) NSAID sulindac and its analog bind RXRalpha and inhibit RXRalpha-dependent AKT signaling. Cancer Cell 17: 560-73 [PMID:20541701]

133. Zimmermann TJ, Niesen FH, Pilka ES, Knapp S, Oppermann U and Maier ME. (2009) Discovery of a potent and selective inhibitor for human carbonyl reductase 1 from propionate scanning applied to the macrolide zearalenone. Bioorg Med Chem 17: 530-6 [PMID:19097799]

134. Zou J, Jin D, Chen W, Wang J, Liu Q, Zhu X and Zhao W. (2005) Selective cyclooxygenase-2 inhibitors from Calophyllum membranaceum. J Nat Prod 68: 1514-8 [PMID:16252917] 